\title{
PENGARUH BERBAGAI JENIS AUKSIN DENGAN BEBERAPA KONSENTRASI TERHADAP PENGAKARAN SETEK MELADA (Piper colubrinum)
}

\section{EFFECT VARIOUS TYPES OF AUXINS WITH SOME CONCENTRATIONS ON ROOTING OF MELADA (Piper colubrinum) CUTTINGS}

\author{
Farida Hanum $^{1 *}$, Yusnita ${ }^{2}$, Dwi Hapsoro ${ }^{2}$ Agustiansyah $^{2}$ dan Agus Karyanto ${ }^{2}$ \\ ${ }^{1}$ Fakultas Pertanian, Universitas Megou Pak Tulang Bawang, Menggala, Indonesia \\ ${ }^{2}$ Fakultas Pertanian, Universitas Lampung, Bandarlampung, Indonesia \\ Email: faridahanum16381@gmail.com \\ * Corresponding Author, Diterima: 1 Sep. 2021, Direvisi: 30 Nov. 2021, Disetujui: 21 Jan. 2022
}

\begin{abstract}
This purpose of research is to determine the effect of various types of auxin on several concentrations in the roots Piper colubrinum. The study was conducted at the Greenhouse of Faculty Agriculture, University of Lampung from May 2018 to December 2018. This study used a completely randomized design with 3 replications. The treatments used were control, IBA 1500 ppm, IBA 2000 ppm, NAA 2000 ppm, NAA 750 ppm + IBA $750 \mathrm{ppm}, N A A 1000 \mathrm{ppm}+I B A 1000 \mathrm{ppm}$. The results showed that the variable number of primary roots in the node that had been treated with NAA $750 \mathrm{ppm}+I B A 750$ ppm showed results that increased the average value of 21 strands compared to control of 2.5 strands. In the treatment of NAA $750 \mathrm{ppm}+I B A 750$ ppm the effect of increasing the number of primary roots in the cross section of the stem was 14 compared to the control 11 strands. Thus the treatment of NAA $750 \mathrm{ppm}+I B A 750 \mathrm{ppm}$ showed its effect on increasing the number of primary roots, namely 34.3 strands compared to 13.5 strands of control. In the root wet weight variable, the average value of NAA $750 \mathrm{ppm}+I B A 750 \mathrm{ppm}$ was $11.8 \mathrm{~g}$, the result of this average value was higher than all treatments.
\end{abstract}

Keywords: Auxin, colubrinum, cuttings, melada, piper.

\begin{abstract}
ABSTRAK
Penelitian ini bertujuan untuk mengetahui pengaruh berbagai jenis auksin terhadap beberapa konsentrasi terhadap pengakaran Piper colubrinum. Percobaan dilaksanakan di Rumah Kaca Fakultas Pertanian Universitas Lampung dari bulan Mei 2018 sampai Desember 2018. Percobaan menggunakan rancangan acak lengkap dengan 3 ulangan. perlakuan yang mengaplikasikan: kontrol, IBA 1500 ppm, IBA 2000 ppm, NAA 2000 ppm, NAA $750 \mathrm{ppm}$ + IBA 750 ppm, NAA $1000 \mathrm{ppm}$ + IBA 1000 ppm. Hasil penelitian menunjukkan bahwa pada variabel jumlah akar primer di buku pada perlakuan NAA $750 \mathrm{ppm}+$ IBA $750 \mathrm{ppm}$ nilai rata-rata meningkat yaitu 21 helai dibandingkan kontrol 2,5 helai. Pada perlakuan NAA $750 \mathrm{ppm}+$ IBA $750 \mathrm{ppm}$ berpengaruh pada peningkatan jumlah akar primer di penampang batang yaitu 14 dibandingkan dengan kontrol 11 helai. Demikian perlakuan NAA $750 \mathrm{ppm}+$ IBA $750 \mathrm{ppm}$ berpengaruh pada peningkatan jumlah akar primer yaitu 34,3 helai dibandingkan dengan kontrol 13,5 helai. Untuk variabel bobot basah akar nilai rata-rata NAA $750 \mathrm{ppm}+$ IBA 750 ppm yaitu $11,8 \mathrm{~g}$, nilai rata-rata ini lebih tinggi dibandingkan semua perlakuan.
\end{abstract}

Kata kunci: Auksin, colubrinum, melada, piper, setek.

\section{PENDAHULUAN}

Lada yang merupakan komoditas strategis yang hasil panennya menurun akibat terserang penyakit busuk pangkal batang. Penyakit busuk pangkal batang disebabkan oleh jamur
Phytophthora capsici pada tahun 1970 kerusakan akibat BPB mencapai 52\% (Manohara et. al., 2005). Kerusakan akibat BPB berkisar $10-15 \%$ per tahun dari total keseluruhan tanaman lada di Indonesia (Kasim, 1990), sampai saat ini.

Untuk mengatasi serangan BPB sudah 
dilakukan beberapa cara yaitu kultur teknis, aplikasi agen hayati dan kimia, dan menciptakan tanaman yang tahan (Wahyuno, 2009). Ada cara lain sebagai alterntif yang belum dikenal luas di Propinsi Lampung yaitu penyambungan batang bawah tanaman yang tahan terhadap penyakit BPB dengan batang atas lada.

Teknik grafting, antara batang atas lada dengan batang bawah P.colubrinum adalah teknik yang dapat digunakan untuk menghindari keterjadian penyakit BPB pada tanaman lada karena P.colubrinum telah diteliti secara bioteknologi terbukti resisten terhadap sejumlah patogen tanaman yaitu Phytophthora capsici (organisme penyebab penyakit busuk pangkal batang) dan nematoda seperti Meloidogyne incognita dan Radopholus similes. Selain itu, P.colubrinum memiliki sistem perakaran kuat dan tahan di beberapa kondisi stres biotik dan abiotik.

Menurut Raja et al., (2018) P.colubrinum species piper yang paling besar persentase pengakarannya yaitu $82,24 \%$ pertumbuhannya lebih cepat sehingga efektif diperbanyak secara setek batang dibandingkan species piper lainnya, sehingga P.colubrinum dapat dengan mudah diperbanyak sebagai batang bawah dalam rangka memproduksi bibit lada sambung.

Setek adalah metode perbanyakan tanaman menggunakan potongan bagian tanaman. Menurut Hartmann et al. (2011) perbanyakan tanaman dengan cara setek dipengaruhi oleh beberapa faktor yaitu: spesies tanaman, kondisi bahan setek, perlakuan pada stek dan kondisi lingkungan. Menurut Agustiansyah et al. (2018) bahwa spesies tanaman, jenis dan konsentrasi ZPT merupakan faktor yang mempengaruhi efektifitas dalam induksi perakaran.

Zat pengatur tumbuh merupakan senyawa organik yang bukan hara banyak mempengaruhi pertumbuhan dan perkembangan pada konsentrasi rendah (Yusnita, 2013; Taiz and Zeiger, 2006), dan menjadi herbisida pada konsentrasi tinggi (Blythe et al, 2007). Auksin adalah salah satu zat pengatur tumbuh yang digunakan untuk merangsang pertumbuhan akar. Perbanyakan secara stek dengan aplikasi auksin dapat meningkatkan inisiasi akar adventif (Taiz and Zeiger, 2002; Hopkins et $a l ., 2008$ ). Jenis auksin yang biasa dipakai untuk setek batang atau daun adalah NAA dan IBA (Hopkins et al.,2008).

Pada penelitian Yusnita et al. (2018) perlakuan auksin paling efektif pada jambu jamaika adalah campuran NAA dan IBA masing-masing 1000 ppm karena menghasilkan akar yang lebih panjang, akar yang lebih baik secara morfologi, persentase bertunas lebih tinggi dan waktu untuk pembentukan akar lebih cepat.

Efek hormon auksin pada pengakaran dan pengembangan tanaman diteliti dalam studi spesies lain seperti Rosemary, Sage dan Elderberry (Gudeva et al., 2017), Ficus benjamina L. (Topacoglu et al., 2016) dengan mengaplikasikan IBA, NAA dan campuran dari masing-masing auksin dilaporkan efektif.

Pada tamanan stek lada varietas Natar 1 perlakuan campuran auksin NAA dan IBA dengan konsentrasi 6000 ppm adalah yang terbaik untuk merangsang pembentukan akar (Artha et al., 2015) pada Piper crocatum Ruizan Pav. konsentrasi NAA 4000 ppm + IBA 1000 ppm adalah yang terbaik untuk merangsang pembentukan akar (Maulida et al., 2014).

Untuk itu penelitian ini penting dilakukan untuk mempelajari teknik yang efisien bagaimana mendapatkan bahan tanaman P.colubrinum dalam jumlah besar untuk batang bawah dalam rangka memproduksi bibit lada sambung.

\section{BAHAN DAN METODE}

Penelitian ini dilaksanakan di Rumah Kaca Fakultas Pertanian Universitas Lampung dari bulan Mei 2018 sampai Desember 2018. Bahan tanaman yang digunakan adalah setek $P$. colubrinum yang didapat dari petani yang berada di desa Sekura kecamatan Teluk Keramat propinsi Kalimantan Barat. Bahan setek yang digunakan diambil dari tunas ortotropik umur rata-rata 2 bulan dengan umur tanaman induk lebih dari 6 bulan, diameter setek adalah $1-1,5 \mathrm{~cm}$ dan panjang $28-35 \mathrm{~cm}$. Tujuan percobaan ini adalah mempelajari pengaruh pemberian beberapa jenis auksin dengan konsentrasi yang berbeda terhadap pengakaran setek $P$. colubrinum.

Setelah percobaan diatas selesai dilakukan, tahap selanjutnya merupakan pembuktian yang berkaitan dengan kompatibilitas. Teknik yang digunakan adalah dengan penyambungan melada sebagai batang bawah dan lada sebagai batang atas. Hasil dari tahapan ini akan dijadikan dasar keputusan penting atau tidaknya penelitian ini dilakukan.

Percobaan ini disusun dengan menggunakan rancangan acak lengkap (RAL) dengan 3 ulangan. Perlakuan percobaan pertama adalah : Kontrol, IBA 1500 ppm, IBA 2000 ppm, NAA 2000 ppm, NAA $750 \mathrm{ppm}$ + IBA $750 \mathrm{ppm}$, NAA $1000 \mathrm{ppm}+$ IBA 1000 ppm. 
Setiap satuan percobaan terdiri dari 5 setek, sehingga jumlah setek keseluruhan adalah 90 setek. Variabel yang diamati adalah persentase setek berakar, jumlah daun, panjang cabang sekunder, tinggi tunas, jumlah cabang primer, jumlah cabang sekunder, jumlah node cabang primer, tinggi batang utama, jumlah akar primer (pada buku dan pangkal penampang batang), panjang akar primer dan bobot basah akar.

Homogenitas ragam diuji dengan uji Bartlett dan jika asumsi terpenuhi maka data dianalisis ragam, kemudian dilanjutkan pemisahan nilai tengah dengan uji BNT pada taraf 0,05 .

Pada percobaan ini auksin yang digunakan adalah IBA dan NAA dengan berbagai taraf konsentrasi. Cara membuat auksin adalah pertama, mempersiapkan alat- alat yaitu gelas ukur, beaker, spatula, timbangan elektrik, dan penutup. Kedua, semua bahan-bahan diukur dan ditimbang sesuai kebutuhan yaitu powder, fungsida, etanol $70 \%$, NAA dan IBA. Ketiga, bahan yg sudah ditimbang yaitu powder dan fungsida dimasukkan kedalam beaker diaduk sampai merata. Keempat, NAA atau IBA yang telah ditimbang dimasukkan kedalam gelas ukur kemudian dilarutkan dengan $10 \mathrm{ml}$ etanol 70\% diaduk hingga larut. Kelima, NAA atau IBA yang sudah larut dimasukkan kedalam beaker yang berisi campuran powder dan fungisida. Keenam, diaduk secara merata dan tidak ada gumpalan. Ketujuh, ditutup dan disimpan dalam ruang dengan suhu $\pm 20 \mathrm{oC}$. Kesembilan, diaduk setiap hari selama satu minggu.

Pengamatan dilakukan setelah tanaman berumur 12 minggu. Kemudian penelitian dilanjutkan dengan uji kompatibilitas penyambungan tanaman melada dan lada.

\section{HASIL DAN PEMBAHASAN}

\subsection{Persentase Setek Berakar}

Hasil percobaan I menunjukkan bahwa pada umur 12 minggu setelah tanam setek P.colubrinum

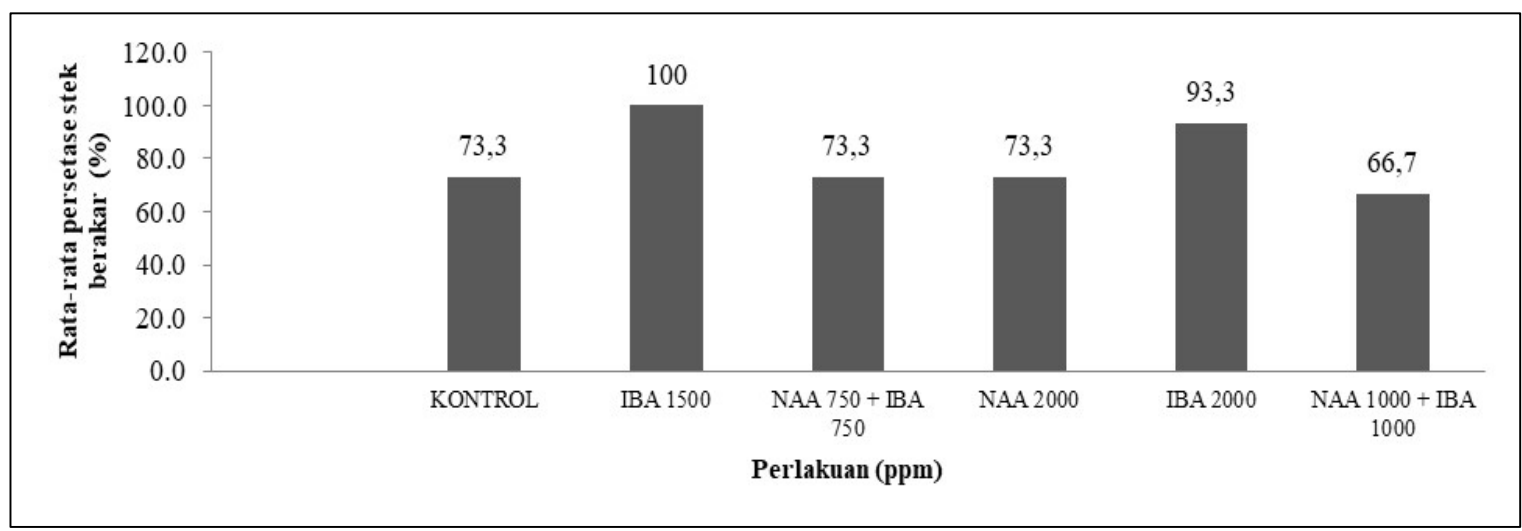

Gambar 1. Grafik Pengaruh IBA, NAA dan Campuran (IBA dan NAA) terhadap Persentase Berakar Setek Melada Umur 12 Minggu Setelah Tanam.

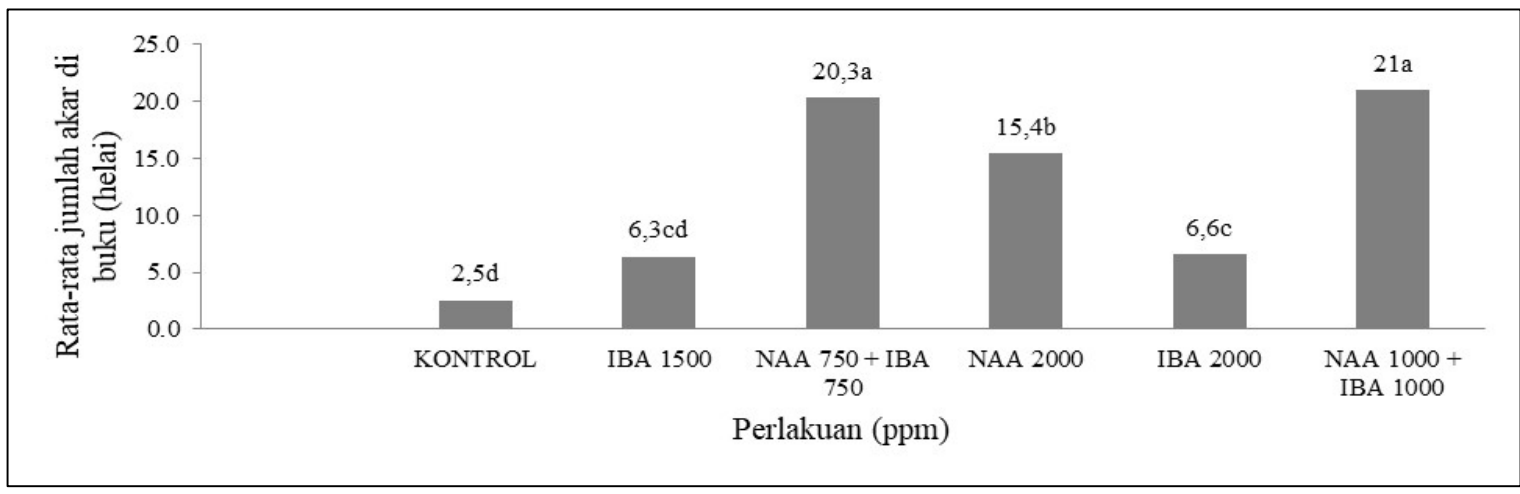

Gambar 2. Pengaruh IBA, NAA Dan Campuran (IBA dan NAA) terhadap Jumlah Akar Primer di Buku Setek Melada Umur 12 Minggu. Nilai Tengah yang Diikuti Huruf yang Sama Tidak Berbeda Nyata Berdasarkan Uji BNT pada Taraf 5\%. Nilai BNT 0,05 Adalah 3,99. 
tanpa auksin memiliki persentase berakar 73,3\%. Perlakuan IBA, NAA atau campuran keduanya pada konsentrasi 1500 dan 2000 ppm menghasilkan nilai persentase berakar yang sama, lebih kecil atau lebih besar dari kontrol.

Perlakuan NAA + IBA pada konsentrasi 1500 ppm dan NAA 2000 ppm menghasilkan persen setek berakar yang sama dengan kontrol yaitu 73,3\%. Perlakuan IBA 1500 ppm dan 2000 ppm menghasilkan persen setek berakar paling tinggi yaitu masing-masing sebesar $100 \%$ dan $93,3 \%$, sedangkan perlakuan NAA + IBA 2500 ppm menghasilkan persen setek berakar terendah yaitu $66,7 \%$ (Gambar 1).

\subsection{Jumlah Akar Primer di Buku}

Perlakuan IBA, NAA dan campuran (IBA dan NAA) dapat meningkatkan jumlah akar primer di buku melada. Rata-rata jumlah akar primer di buku setek melada tertinggi dengan perlakuan NAA 1000 ppm + IBA 1000 ppm yaitu 21 helai dan ratarata terkecil kontrol yaitu 2,5 helai. Perlakuan NAA $750 \mathrm{ppm}$ + IBA 750 ppm, NAA 2000 ppm, IBA 2000 ppm, dan IBA 1500 ppm yaitu 20,3 helai, 15,4 helai, 6,6 helai, dan 6,3 helai. Hasil nilai rata-rata dapat dilihat pada grafik Gambar 2.

\subsection{Jumlah Akar Primer di Penampang Batang}

Perlakuan campuran (IBA dan NAA) dapat meningkatkan jumlah akar primer di penampang batang melada. Berdasarkan grafik Gambar 3, ratarata jumlah akar primer di penampang batang setek melada terbesar dengan perlakuan NAA $1000 \mathrm{ppm}$ + IBA 1000 ppm yaitu 19,7 helai dan rata-rata terkecil perlakuan IBA 1500 ppm yaitu 10,6 helai. Perlakuan NAA 750 ppm + IBA 750 ppm, NAA 2000 ppm, IBA 2000 ppm, dan kontrol yaitu 14,03 helai, 12,06 helai, 11,25 helai, dan 11,03 helai.

\subsection{Jumlah Akar Primer di Penampang Batang}

Perlakuan campuran (IBA dan NAA) dapat meningkatkan jumlah akar primer di penampang batang melada. Berdasarkan grafik Gambar 3, ratarata jumlah akar primer di penampang batang setek melada terbesar dengan perlakuan NAA $1000 \mathrm{ppm}$ + IBA 1000 ppm yaitu 19,7 helai dan rata-rata terkecil perlakuan IBA 1500 ppm yaitu 10,6 helai. Perlakuan NAA 750 ppm + IBA 750 ppm, NAA 2000 ppm, IBA 2000 ppm, dan kontrol yaitu 14,03 helai, 12,06 helai, 11,25 helai, dan 11,03 helai.

\subsection{Jumlah Akar Primer}

Perlakuan campuran (IBA dan NAA) dapat meningkatkan jumlah akar primer batang melada. Berdasarkan grafik Gambar 4, rata-rata jumlah akar primer setek melada terbesar dengan perlakuan NAA 1000 ppm + IBA 1000 ppm yaitu 40,7 helai dan rata-rata terkecil perlakuan kontrol yaitu 13,5 helai. Perlakuan NAA $750 \mathrm{ppm}+$ IBA $750 \mathrm{ppm}$, NAA 2000 ppm, IBA 2000 ppm, dan IBA 1500 ppm yaitu 34,3 helai, 27,5 helai, 17,8 helai dan 16,9 helai.

\subsection{Panjang Akar Primer}

Perlakuan IBA, NAA dan campuran (NAA dan IBA) tidak meningkatkan panjang akar primer pada melada. Rata-rata panjang akar primer setek melada terbesar dengan perlakuan IBA 1500 ppm

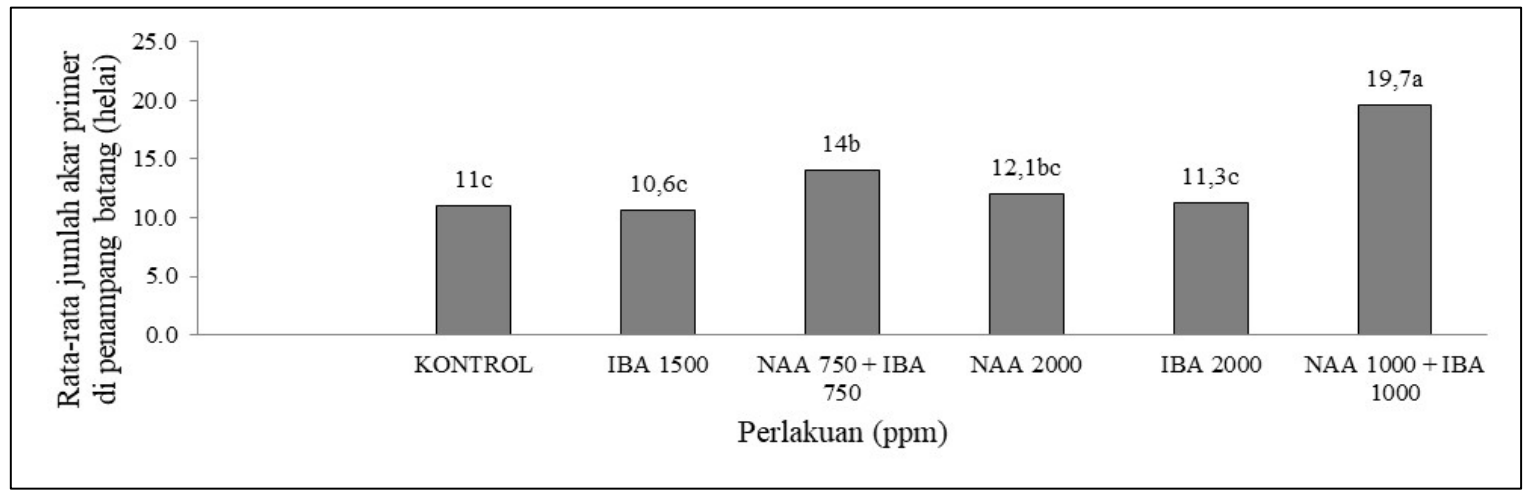

Gambar 3. Pengaruh IBA, NAA dan Campuran (IBA dan NAA) terhadap Jumlah Akar Primer di Penampang Batang Setek Melada Umur 12 Minggu Setelah Tanam. Nilai Tengah yang Diikuti Huruf yang Sama Tidak Berbeda Nyata Berdasarkan Uji BNT Pada Taraf 5\%. Nilai BNT 0,05 Adalah 2,18. 
yaitu $21,5 \mathrm{~cm}$ dan rata-rata terkecil perlakuan NAA $2000 \mathrm{ppm}$ yaitu $17,4 \mathrm{~cm}$. Perlakuan NAA $750 \mathrm{ppm}$ + IBA 750 ppm, NAA 1000 ppm + IBA 1000 ppm, IBA 2000 ppm, dan kontrol yaitu 20,6 cm, 19,4 cm, $19,4 \mathrm{~cm}$ dan $18,4 \mathrm{~cm}$. Hasil rata-rata dapat dilihat pada grafik Gambar 5.

\subsection{Bobot Basah}

Pemberian campuran (NAA dan IBA) dapat meningkatkan bobot basah akar pada melada. Rata-rata bobot basah akar setek melada terbesar dengan perlakuan NAA $750 \mathrm{ppm}+$ IBA $750 \mathrm{ppm}$ yaitu $11,8 \mathrm{~g}$ dan rata-rata terkecil perlakuan IBA 2000 ppm yaitu 3,3 g. Perlakuan NAA 1000 ppm + IBA 1000 ppm, IBA 1500 ppm, kontrol dan NAA 2000 ppm yaitu $8 \mathrm{~g}, 4,8 \mathrm{~g}, 4,08 \mathrm{~g}$ dan $3,3 \mathrm{~g}$. Hasil rata-rata bobot basah akar dapat dilihat pada grafik Gambar 6. Performa akar dapat dilihat pada Gambar 7.

Auksin banyak digunakan dalam perbanyakan vegetatif, salah satunya adalah perbanyakan dengan cara setek. Dengan mengaplikasikan auksin mampu memacu pembentukan akar adventif (Hopkins et al., 2008).

Konsentrasi auksin merupakan variabel penting dalam pembentukan akar yang menjadi faktor penting yang mempengaruhi tanggapan perkembangan dan pertumbuhan diferensial terhadap cahaya dan gravitasi (Hopkins et al. 2008; Overvoorde et al. 2010).

Faktor lain yang mempengaruhi penyetekan yaitu spesies tanaman, faktor lingkungan, keadaan setek, dan perlakuan setek (Hartmann et al., 2011). Berdasarkan hasil penelitian perlakuan IBA 1500 ppm dan IBA 2000 ppm memliki pengaruh yang berbeda-beda terhadap masing-masing variabel pengamatan tanaman melada. Pengunaan auksin tunggal IBA $1500 \mathrm{ppm}$ dapat meningkatkan persentase setek berakar, jumlah akar primer di buku, jumlah akar primer, bobot basah akar, tinggi tunas dan tinggi batang utama dibandingkan dengan kontrol. Pengaplikasian IBA 2000 ppm dapat meningkatkan persentase setek berakar, akar primer di buku, akar primer di penampang batang, jumlah akar primer, tinggi tunas dan tinggi batang utama

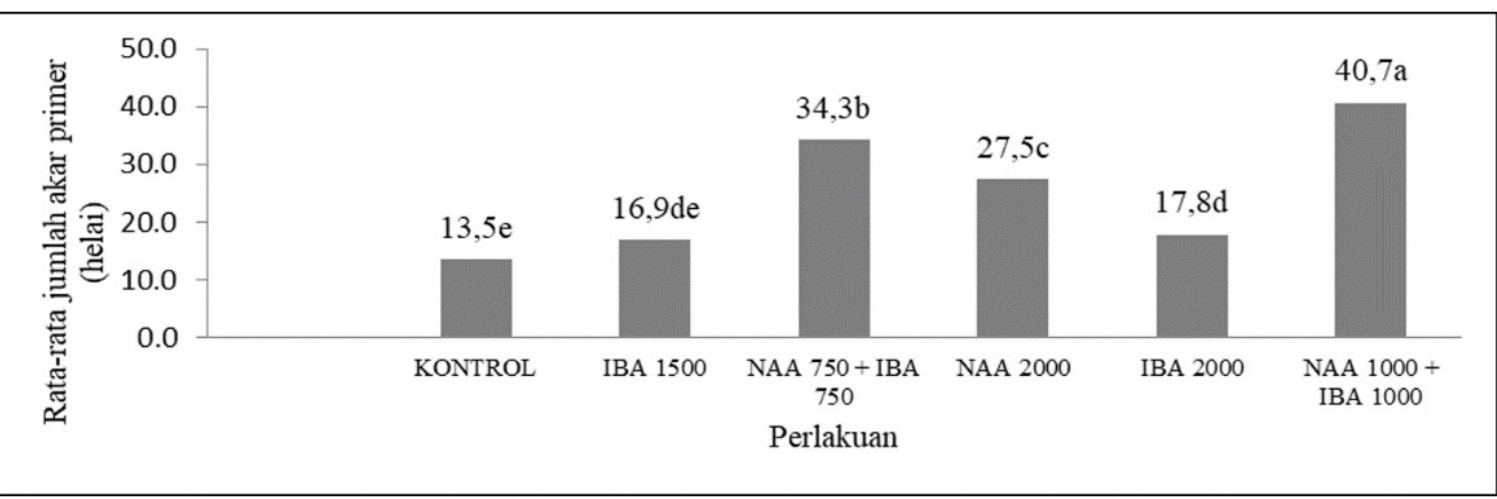

Gambar 4. Pengaruh IBA, NAA dan Campuran (IBA dan NAA) terhadap Jumlah Akar Primer Setek Melada Umur 12 Minggu Setelah Tanam. Nilai Tengah yang Diikuti Huruf yang Sama Tidak Berbeda Nyata Berdasarkan Uji BNT pada Taraf 5\%. Nilai BNT 0,05 Adalah 3,75.

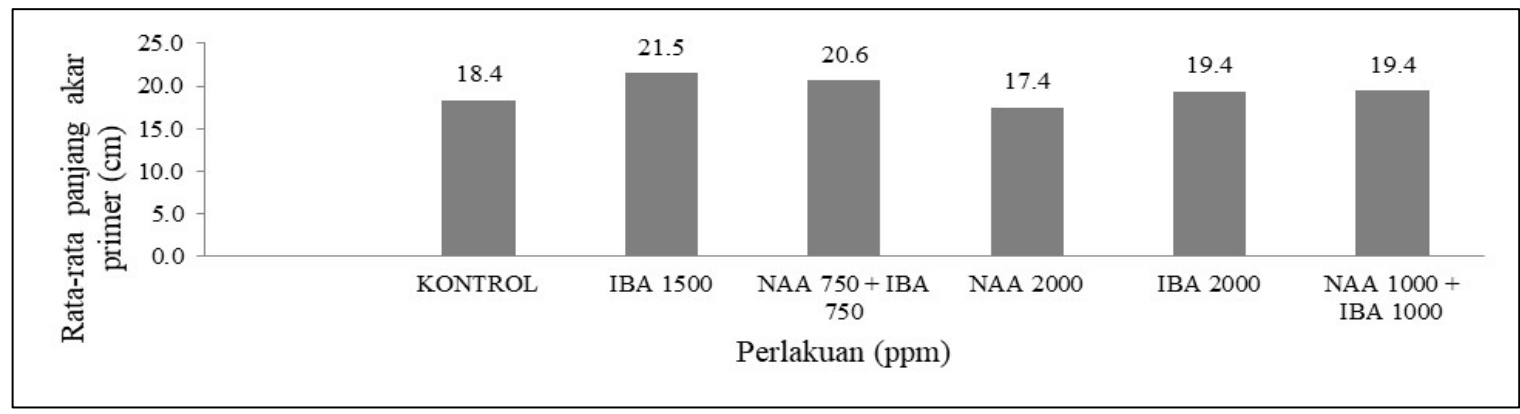

Gambar 5. Pengaruh IBA, NAA dan Campuran (IBA dan NAA) terhadap Panjang Akar Primer Setek Melada Umur 12 Minggu Setelah Tanam. 


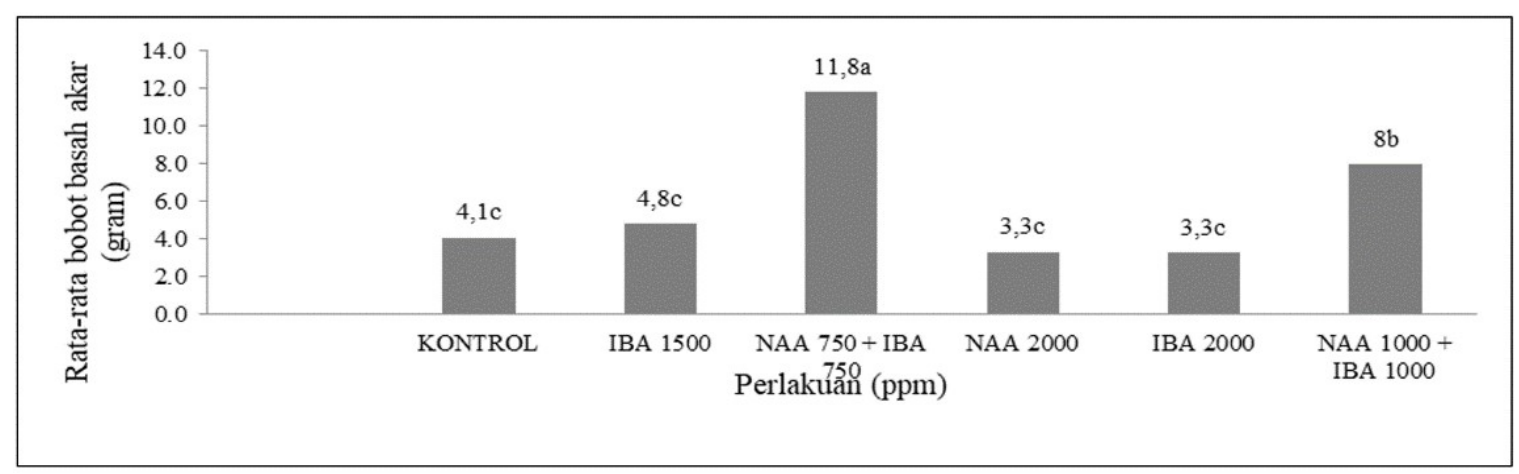

Gambar 6. Grafik Pengaruh IBA, NAA dan Campuran (IBA dan NAA) terhadap Bobot Basah Akar Setek Melada Umur 12 Minggu Setelah Tanam. Nilai Tengah yang Diikuti Huruf yang Sama Tidak Berbeda Nyata Berdasarkan Uji BNT pada Taraf 5\%. Nilai BNT 0,05 Adalah 2,01.
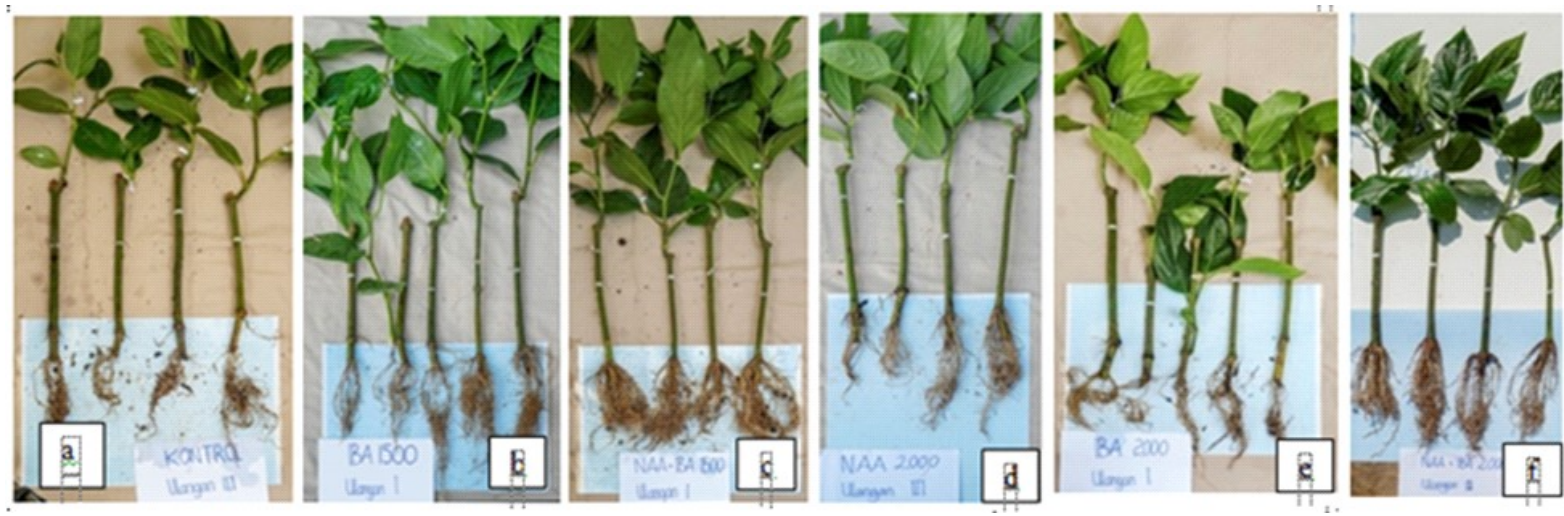

Gambar 7. Performa Tanaman dengan Perlakuan a) Kontrol, b) IBA 1500 ppm, c) NAA 750 ppm + IBA 750 ppm, d) NAA 2000 ppm, e) IBA 2000 ppm, dan f) NAA 1000 ppm + IBA 1000 ppm.

Persentase setek berakar dengan perlakuan IBA 1500 ppm dan IBA 2000 ppm secara nyata dapat meningkat dibandingkan dengan kontrol. Penambahan konsentrasi IBA dari 1500 ppm menjadi 2000 ppm tidak efektif untuk meningkatkan persentase setek berakar. Pemberian IBA 1500 ppm persentase berakar $100 \%$, setelah diberikan penambahan menjadi $2000 \mathrm{ppm}$ mengalami penurunan persentase berakar menjadi 93,3\%. Demikian juga pada variabel bobot basah akar, tinggi tunas, dan tinggi batang utama. Penambahan konsentrasi efektif pada peningkatan jumlah akar primer di buku, jumlah akar primer di pangkal batang dan jumlah akar primer. Pada variabel jumlah akar di buku, jumlah akar di penampang batang dan jumlah akar primer pemberian IBA 2000 ppm lebih baik dibandingkan kontrol karena terjadi peningkatan rata-rata. Rata-rata jumlah akar di buku pada kontrol 2,5 helai, setelah diberi perlakuan IBA 2000 ppm meningkat menjadi 6,6 helai. Ratarata jumlah akar primer di penampang batang dari 11 helai menjadi 11,3 helai. Demikian juga rata-rata jumlah akar dari 17,83 helai menjadi 13,53 helai.

Perlakuan NAA 2000 ppm tidak signifikan terhadap peningkatan persentase setek berakar melada dibandingkan kontrol. Persentase berakar kontrol sama dengan perlakuan NAA 2000 ppm yaitu $73,33 \%$. Perlakuan NAA 2000 ppm signifikan terhadap peningkatan jumlah akar primer di buku 2,5 helai meningkat menjadi 15,4 helai. Peningkatan juga terjadi pada jumlah akar primer di penampang batang 10,6 helai meningkat menjadi 12,1. Demikian pada variabel jumlah akar primer dari nilai 13,5 helai menjadi 27,5 helai. Perlakuan NAA 2000 ppm juga berpengaruh pada peningkatan tinggi batang utama dan tinggi tunas.

Perlakuan auksin campuran NAA dan IBA memberikan pengaruh yang berbeda terhadap variabel. Perlakuan NAA 750 ppm + IBA 750 ppm dapat meningkatkan tinggi batang utama, akar primer di buku, akar primer di penampang batang, jumlah akar primer, bobot basah akar dan tinggi tunas setek melada dibandingkan dengan kontrol. Namun tidak berpengaruh pada variabel persentase 

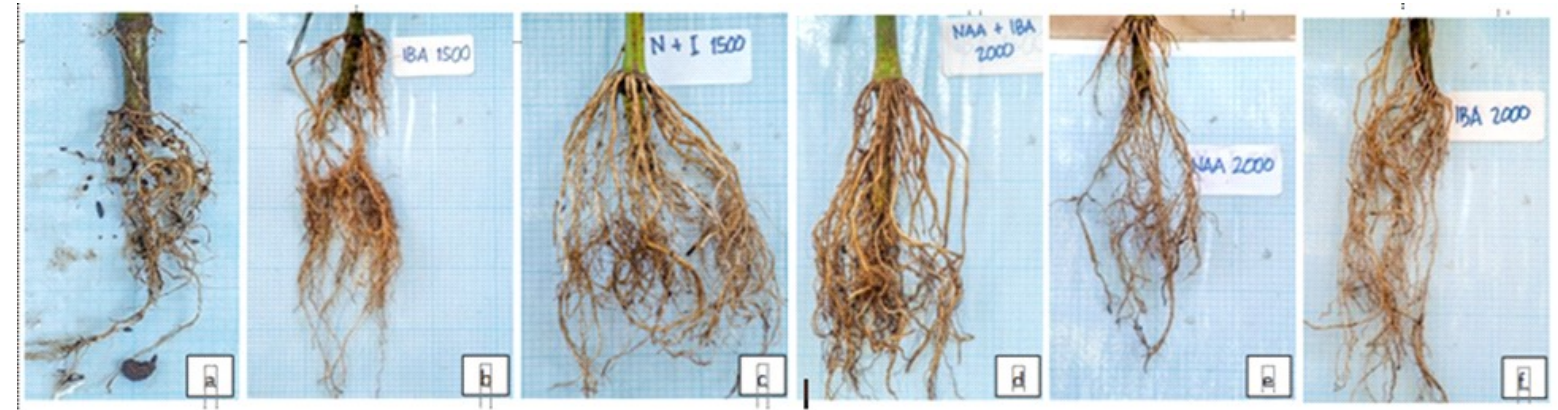

Gambar 8. Performa Akar Perlakuan a) Kontrol, b) IBA 1500 ppm, c) NAA 750 ppm + IBA 750 ppm, d) NAA $2000 \mathrm{ppm}$, e) IBA $2000 \mathrm{ppm}$ dan f) NAA $1000 \mathrm{ppm}+$ IBA $1000 \mathrm{ppm}$.

setek berakar. Perlakuan NAA 1000 ppm + IBA $1000 \mathrm{ppm}$ berpengaruh nyata terhadap peningkatan jumlah akar primer di buku, jumlah akar primer di penampang batang, jumlah akar primer, bobot basah akar, tinggi tunas dan tinggi batang utama dibandingkan dengan kontrol. Tetapi tidak berpengaruh terhadap persentase setek berakar.

Perlakuan NAA $750 \mathrm{ppm}+$ IBA $750 \mathrm{ppm}$ tidak berpengaruh terhadap persentase setek berakar melada dibandingkan dengan perlakuan kontrol yaitu 73,33\%. Pada variabel jumlah akar primer di buku pada perlakuan NAA $750 \mathrm{ppm}+$ IBA $750 \mathrm{ppm}$ nilai rata-rata meningkat yaitu 21 helai dibandingkan kontrol 2,5 helai. Peningkatan jumlah helai akar primer pada NAA + IBA total 1500 ppm lebih tinggi dibandingkan perlakuan NAA 2000 ppm, IBA 2000 ppm dan IBA 1500 ppm. Pada perlakuan NAA 750 ppm + IBA 750 ppm berpengaruh pada peningkatan jumlah akar primer di penampang batang yaitu 14 dibandingkan dengan kontrol 11 helai. Demikian perlakuan NAA $750 \mathrm{ppm}$ + IBA $750 \mathrm{ppm}$ berpengaruh pada peningkatan jumlah akar primer yaitu 34,3 helai dibandingkan dengan kontrol 13,5 helai. Lebih tinggi peningkatannya dibandingkan NAA 2000 ppm, IBA 2000 ppm dan IBA 1500 ppm, untuk variabel bobot basah akar nilai rata-rata NAA 750 ppm + IBA 750 ppm yaitu 11,8 g, nilai rata-rata ini lebih tinggi dibandingkan semua perlakuan.

Perlakuan NAA 1000 ppm + IBA 1000 ppm persentase setek berakar sama dengan kontrol yaitu $73,33 \%$ sedangkan NAA 1000 ppm + IBA 1000 ppm $66,67 \%$. Persentase setek berakar pada perlakuan kontrol dibandingkan dengan perlakuan berbagai jenis auksin yaitu sama bahkan lebih kecil. Menurut Hartmann et al. (2011) perbanyakan tanaman dengan cara setek dipengaruhi oleh beberapa faktor yaitu : spesies tanaman, kondisi bahan setek, perlakuan pada stek dan kondisi lingkungan.

Pada penelitan ini, salah satu faktor yang penyebab persentase setek berakar melada lebih tinggi kontrol dibandingkan perlakuan auksin adalah keadaan setek melada. Perlu diketahui bahwa bahan setek melada yang digunakan pada penelitian berasal dari Kalimantan yang pengirimannya 5-7 hari sehingga mempengaruhi kualitas setek dan juga mempengaruhi persentase setek berakar.

Perlakuan NAA 1000 ppm + IBA 1000 ppm dapat meningkatkan jumlah akar di buku, jumlah akar di penampang batang, jumlah akar primer dan bobot akar dibandingkan perlakuan kontrol, NAA 2000 ppm, IBA 2000 ppm, IBA 1500 ppm.

Berdasarkan penelitian diatas kombinasi NAA dan IBA lebih efektif dalam pengakaran melada karena menghasilkan jumlah akar primer di buku, jumlah akar primer di penampang batang, jumlah akar primer dan bobot basar akar yang lebih tinggi dibandingkan dengan perlakuan auksin tunggal. Hasil penelitian diatas sesuai dengan penelitian yang dilaporkan Rahdari et al. (2014) bahwa mengaplikasikan kombinasi NAA dan IBA lebih efektif dibandingkan penggunaan secara tunggal NAA atau IBA saja. Hal yang sama dituliskan dalam penelitian Yusnita et al. (2018) perlakuan campuran NAA dan IBA masing-masing 1000 ppm lebih efektif karena menghasilkan panjang akar yang lebih besar, akar lebih baik secara morfologi, persentase bertunas lebih tinggi dan waktu untuk pembentukan akar lebih cepat pada jambu jamaika. Perlakuan kombinasi NAA dan IBA juga efektif pada Ficus benjamina L. menurut Topacoglu et. al. (2016), setek lada varietas Natar 1 (Artha et. al., 2015) dan Piper crocatum Ruizan Pav. (Maulida et. al., 2014).

Morfologi akar dengan perlakuan kombinasi lebih baik dibandingkan perlakuan auksin tunggal (Gambar 8 ) karena terlihat perlakuan kombinasi akar primer yang muncul lebih kekar, jumlah akar primer di buku dan jumlah akar primer di penampang batang juga lebih banyak. Dalam 
Hopkins et. al. (2010) dituliskan bahwa IBA dan NAA dapat meningkatkan pembentukan akar adventif.

Dari hasil penelitian dapat diketahui bahwa jenis auksin dan kemenambahan konsentrasi dapat mempengaruhi pengakaran setek melada. Penambahan konsentrasi pada auksin baik tunggal maupun campuran meningkatkan jumlah helai akar primer tetapi menurunkan persentase berakar setek dan bobot basah akar.

Dalam penelitian Yusnita et al. (2018), faktor lain yang mempengaruhi pengakaran yaitu ketersediaan auksin pada saat inisiasi akar. Auksin endogen hanya mampu mencukupi setengah dari auksin yang dibutuhkan selama tahap auksin aktif dalam inisiasi akar. Tahap auksin aktif merupakan proses yang membutuhkan keberadaan auksin secara terus menerus. Sedangkan auksin yang tersedia tidak mampu secara signifikan berpengaruh terhadap pembentukan akar.

Dengan mengaplikasikan secara eksogen IBA dan NAA terhadap setek, dapat dipastikan ketersediaan auksin selama proses auksin aktif. Sehingga proses pembentukan akar akan lebih mudah dan lebih cepat.

Dengan mengaplikasikan auksin IBA dan NAA dapat meningkatkan akar primer pada bagian buku setek melada. Semakin banyak jumlah akar adventif yang muncul pada buku akar setek melada maka tanaman melada sebagai batang bawah semakin kokoh menopang batang atas (lada) dan dapat tahan pada kondisi stres abiotik. Selain itu yang lebih penting, dapat menghidari penyakit BPB pada bibit lada.

Dari pembahasan, perlakuan auksin campuran selain pengaruhnya lebih baik terhadap pengakaran dan juga atas dasar pertimbangan biaya. Menurut Yusnita (2018), harga IBA tujuh hingga empat belas kali lipat lebih mahal dibandingkan harga NAA untuk jumlah yang sama. Harga IBA $5 \mathrm{~g}$ dan $25 \mathrm{~g}$ pada Desember tahun 2017 adalah US \$ 29.00 dan US $\$ 87.00$, sedangkan harga NAA $25 \mathrm{~g}$ dan $500 \mathrm{~g}$ adalah US \$ 20.00 dan US \$ 121.00 .

\section{KESIMPULAN}

Berdasarkan hasil penelitian dari percobaan tersebut dapat disimpulkan sebagai berikut: IBA dan NAA, baik sendiri-sendiri maupun campuran efektif untuk merangsang pengakaran setek melada, campuran NAA dan IBA lebih lebih efektif dari pada NAA saja atau IBA saja dalam merangsang pengakaran setek melada, NAA lebih efektif dibandingkan IBA dalam merangsang pengakaran setek melada yang ditunjukkan oleh variabel jumlah akar primer di buku, jumlah akar primer di penampang dan jumlah akar primer dan campuran NAA $750 \mathrm{ppm}$ + IBA $750 \mathrm{ppm}$ dan campuran NAA $1000 \mathrm{ppm}+$ IBA $1000 \mathrm{ppm}$ paling efektif dalam merangsang akar setek melada.

\section{UCAPAN TERIMA KASIH}

Terimakasih kasih kepada Fakultas Pertanian Universitas Lampung yang telah memberikan fasilitas baik sarana maupun prasarana kepada penulis dalam melakukan penelitian ini.

\section{DAFTAR PUSTAKA}

Agustiansyah, A., Jamaludin, J.,Yusnita, Y., dan Hapsoro, D. 2018. NAA lebih efektif dibandingkan iba untuk pembentukan akar pada cangkok jambu bol (Syzygium malaccense (L.) Merr \& Perry). J. Hort. Indonesia. 9 (1): 1-9.

Artha, D. D., Yusnita, and Sugiatno. 2015. Pengaruh aplikasi kombinasi NAA (naphtaleneacetic acid) dan IBA (indole butyric acid) terhadap pengakaran stek lada (Piper nigrum Linn) Varietas Natar 1. J. Agrotek Trop. 3: 1-6.

Blythe, E.K., Sibley, J.L., Ruter, J.M. and Tilt, K.M.. 2004. Cutting Propagation of Foliage Crops Using a Foliar Application of Auxin. Scientia Horticulturae. 103: 31-37.

Gudeva, L., Trajkova, F., Mihajlov, L., and Troicki, J. 2017. Influence of different auxins on rooting of rosemary, sage and elderberry. Annual Research \& Review in Biology, 12(5), 1-8.

Hartmann, H. T., Kester, D. E., Davies, JR. F. T., and Geneve, R.L. 2011. Plant Propagation Principles And Practices. Eighth Edition. Prentice Hall Internatinal Inc. New Jersey. 869p.

Hopkins, W. G. and Hüner, N. P. A. 2008. Introduction to Plant Physiology. Fourth Edition. John Wiley and Sons, Inc. Ontario.

Kasim, R. 1990. Pengendalian Penyakit Busuk Pangkal Batang Secara Terpadu. Bull. Tanaman Industri $1:$ 16-20.

Manohara, D., Wahyuno, D., dan Rita, N. 2005. Penyakit Busuk Pangkal Batang Tanaman Lada dan Strategi Pengendaliannya. Perkembangan Teknologi Tanaman Rempah dan Obat. Vol 17(2): 41-45 
Maulida, D., Rugayah, dan Andalasari, T. D. 2014. Pengaruh Pemberian IBA (Indole Butyric Acid) dan Konsentrasi NAA (Naphthaleneacetic Acid) Terhadap Keberhasilan Penyetekan Sirih Merah (Piper crocatum Ruiz And Pav.). 2(1): 11-17.1

Overvoorde, P., Fukaki, H., and Beeckman, T. 2010. Auxin control of root development. Cold Spring Harbor Perspectives in Biology, 2(6).

Rahdari, P., Khosroabadi, M., Delfani, K., and Hoseini, S.,M. 2014. Effect of different concentration of plant hormones (IBA and NAA) on rooting and growth factors in root and stem cuttings of Cordyline terminalis. Journalof Medical and Bioengineering, 3(3), 190-194.

Raja, M. B., Parthiban, S., Anandhan, M., Venkadeswaran, E., Pandi, K., Suganthi, S., and Prakash, M. S. 2018. Rooting and sprouting performance of nodal cutting of cultivated and wild inter specific Piper rootstocks, Internasional Journal of Chemical Studies, 6(2), 20-24.
Taiz, L., and Zeiger, E. 2006. Plant Physiology . Fourth Edition. Sinauer Associates, Inc., Sunderland, MA.

Topacoglu, L., Sevik, H., Guney, K., Unal, C., Akkuzu, E., and Sivacioglu, A. 2016. Effect of rooting hormones on the rooting capability of Ficus benjamina L. cuttings. Sumarski list,1-2 (2016): 39-44. https:// www.researchgate.net/publication/ 298714351. Diakses tanggal 21 Oktober 2018.

Wahyuno, D. 2009. Pengendalian terpadu busuk pangkal batang lada. Perspektif, Vol 8(1): $17-29$.

Yusnita, Y. 2013. Kultur Jaringan Tanaman Pisang. Anugrah Utama Raharja. Jakarta. $172 \mathrm{hlm}$.

Yusnita, Y., Jamaludin, J., Agustiansyah, A., and Hapsoro, D. 2018. Combination of IBA and NAA resulted in better rooting and shoot sprouting than single auxin on malay apple [Syzygium malaccense (L.) Merr. \& Perry] stem cuttings. AGRIVITA Journal of Agricultural Science. 40(1), 80-90. 